\title{
(2) \\ Knowledge and Consumption of Wild Plants: A comparative study in two Tsimane' villages in the Bolivian Amazon
}

\author{
Victoria Reyes-García, Vincent Vadez, Tomás \\ Huanca, William Leonard and David Wilkie
}

\begin{abstract}
Researchers have often equated ethnobotanical knowledge collected through interview questions with actual uses of plants, but knowledge and uses of plants might or might not move in lockstep. Using data from 132 adults living in two villages of a foraging-farming society in the Bolivian Amazon, the Tsimane', we compare ethnobotanical knowledge with uses of wild and semi-domesticated plants. Villages differed in proximity to the market town and in dependence on forest resources. We find that people in the more remote village knew and used more plants than did people in the accessible village. We also find that individual ethnobotanical knowledge correlates positively with uses of plants in the pooled sample and in the isolated village, but not in the village with less dependence on forest resources. Researchers could use the gap between ethnobotanical knowledge and actual uses of plants to study erosion of ethnobotanical knowledge.
\end{abstract}

\section{Introduction}

Researchers have used different methods to study the ethnobotanical knowledge of groups and individuals. Most of this research has been based in transect's surveys, specimens identifications (Hunn 2002, Zarger \& Stepp 2004, Zent 2001), and answers to several types of interview questions (Begossi 1996, Atran et al. 2002, ReyesGarcía et al. 2005, Godoy et al. 1998). But ethnobotanical research stills needs to advance our understanding of the relation between the ethnobotanical knowledge reported in interviews and respondent's actual uses of plants.

Researchers have often equated ethnobotanical knowledge collected through interview questions with actual uses of plants (Rossato et al.1999, Figueiredo et al. 1997), but knowledge and uses of plants might or might not move in lockstep. The common assumption would be that ethnobotanical knowledge and uses of plants should cor-

relate positively. People who have higher ethnobotanical knowledge can use more plant species and for more ends than people who have less ethnobotanical knowledge. Or the other way around, people who use more plants, interact more with the environment, thus increasing their ethnobotanical knowledge. But, although the common wisdom predicts a positive relation between ethnobotanical knowledge and actual uses of plants, results from the few studies that differentiate between ethnobotanical knowledge and uses of plants show that the two variables do not necessarily correlate (Begossi et al. 2002, Phillips 1996, Byg \& Balslev 2001, Ladio \& Lozada 2004). For example, Byg and Balslev (2001) conducted interview questions and observations on the knowledge and use of Dypsis fibrosa (Arecaceae) in Eastern Madagascar $(n=54)$. They found that there is not always a strict correlation between an individual's ethnobotanical knowledge, as elicited in surveys, and the actual extent of use of different plant resources by the same individual. Similarly, in a study among the Mapuche from northwestern Patagonia, Ladio and Lozada (2004) found that people know significantly more edible plants that they consume. They found a higher difference among forest plants than among

\section{Correspondence}

Victoria Reyes-García, ICREA-Institut de Ciència i Tecnologia Ambiental, Universitat Autónoma de Barcelona, 08193 Bellatera, Barcelona, SPAIN. vreyes@brandeis.edu

Victoria Reyes-Garcia, Vincent Vadez \& Tomás Huanca, Sustainable International Development Program, Heller School for Social Policy and Management, Brandeis University, Waltham, Massachusetts 02454-9110, U.S.A.

William Leonard, Department of Anthropology, Northwestern University, Evanston, Illinois 60208, U.S.A.

David Wilkie, Wildlife Conservation Society, 18 Clark Lane, Waltham, Massachusetts 02451-1823, U.S.A.

Ethnobotany Research \& Applications 3:201-207 (2005) 
plants found in dwellings and steppes. In sum, there is few research on the relation between individual ethnobotanical knowledge and uses of plants, but this research suggests that, contrary to what common wisdom predicts, the two variables do not necessarily correlate.

In this article we compare how individual ethnobotanical knowledge of wild and semi-cultivated plants correlate with individual uses of plants. For the empirical analysis, we use data from two villages with different levels of exposure to the market. Data comes from the Tsimane', a foraging and farming Amerindian society in the Bolivian Amazon. We do the comparison at two different levels. First, we compare the general ethnobotanical knowledge and uses of plants between two villages of the same ethnic group that differed in proximity to the market town and dependence on the forest. Second, we compare a person's ethnobotanical knowledge with the person's uses of plants. In particular, we want to know whether people who know more about plants also use plants more often and for more ends than people with less ethnobotanical knowledge, and whether this relation is similar in villages experiencing different levels of contacts with the market society.

Our study of the relation between ethnobotanical knowledge and uses of plants matters for two reasons. First, as we just explained, the few researchers that have empirically tested the relation between ethnobotanical knowledge and uses of plants have found that ethnobotanical knowledge and uses of plants do not necessarily correlate (Byg \& Balslev 2001, Ladio \& Lozada 2004). By comparing ethnobotanical knowledge and uses of plants in two communities with different levels of socio-economic change, we can test whether the discrepancies between ethnobotanical knowledge and uses of plants found in previous research are mainly due to the socio-economic changes faced nowadays by indigenous people. We do not know of any study that compares the relation between ethnobotanical knowledge and uses of plants in villages with different level of exposure to socio-economic change.

Second, the comparison between ethnobotanical knowledge and uses of plants can contribute to understand how the erosion of traditional knowledge occurs. Researchers have identified several causes behind the loss of ethnobotanical knowledge (Casagrande 2002, Hewlett \& Cavalli-Sforza 1986, Hunn 2002, Ohmagari \& Berkes 1997, Zarger 2002). Some researchers argue that modernization (Benz et al. 2000) and access to substitutes for plant products (Byg \& Balslev 2001) erode ethnobotanical knowledge. But the hypothesis is difficult to test because changes in levels of ethnobotanical knowledge occur over long periods of time and researchers often lack long-term data. An alternative path to redress the lack of long-term data to study the loss of ethnobotanical knowledge is to study the loss of uses of plants as a proxy variable. Be- fore one can undertake such a study, one needs to test the assumed relation between ethnobotanical knowledge and uses of plants.

\section{The Tsimane': Habitat and economy}

The Tsimane' are a foraging and farming society in the Bolivian department of Beni. The Tsimane' territory spreads from the foothills of the Andes to the northeast, reaching the edges of the Moxos savanna (14 $35^{\prime} \mathrm{S}-15^{\circ} 30^{\prime} \mathrm{S}$; $\left.66^{\circ} 23^{\prime} \mathrm{W}-67^{\circ} 10^{\prime} \mathrm{W}\right)$. Habitats in Tsimane' territory range from wet to moist sub-tropical and gallery forests, some of which abut savannas (Killeen et al. 1993). Recent dissertations (Byron 2003, Ellis 1996) and publications (Vadez et al. 2004) provide detailed ethnographic information on the Tsimane', including analysis of the use of fauna (Chicchon 1992), management of traditionally cultivated plants (Huanca 1999), and uses of wild plants (Reyes-García 2001, 2006).

The Tsimane' represent an ideal group to compare knowledge and uses of plants for three reasons. First, the Tsimane' depend heavily on forest goods. Tsimane' household income includes wage earnings, sale of goods, goods obtained in barter, and the value of farm and forest goods consumed in the household. Among those sources, Tsimane' households mostly rely on forest goods and subsistence agriculture (Godoy et al. 2002, Reyes-García 2001). Consumption of forest goods represents an average of US $\$ 842$ per household/year, or $45 \%$ of total Tsimane' household income. Tsimane' obtain game, fish, and wild and semi-cultivated plants from the forest. Tsimane' use wild and semi-cultivated plants for food, firewood, medicines, and to build houses, canoes, and handicrafts. Tsimane' gather wild and semi-cultivated plants all year, mostly near cultivated and recently abandoned plots and during trips to the forest. The annual value of plants that Tsimane' gather hovers around $17 \%$ of the total household income, with an average annual value of US \$ 268 per household (Reyes-García 2001). Consumption of agricultural goods represents an average of $33 \%$ of the total annual household income, or US \$ 618 per household/ year and cash income accounts for only $15 \%$ of the total annual household income, or US \$ 292 per household/ year.

Second, Tsimane' share widely knowledge of plant uses. In a previous study (Reyes-García et al. 2003), we assessed the degree to which 511 Tsimane' adults living in 59 villages shared ethnobotanical knowledge. We found that knowledge of plant uses was strongly shared by all Tsimane' irrespective of socio-demographic and ecological differences. Higher levels of agreement were found between people living in the same village than between people living in different villages. 


\section{Reyes-Garcia et al. - Knowledge and Consumption of Wild Plants: A comparative study in two Tsimane' villages in the Bolivian Amazon}

Last, we find much variation at the individual and at the village level both in dependence on the forest (Godoy et al. 2002) and in ethnobotanical knowledge (Reyes-García et al. 2005). Although all Tsimane' depend on the forest to certain degree, not all them do it to the same extend. Tsimane' living far from towns still depend mostly on the forest for their subsistence, but Tsimane' living close to towns often work for wages in the homesteads of colonist farmers and cattle ranches (Vadez et al. 2004a). Similarly, although all Tsimane' share ethnobotanical knowledge, Tsimane' living far from the market town have higher levels of ethnobotanical knowledge than Tsimane' living close to the market town (Reyes-García et al. 2005).

\section{Methods}

Two anthropologists, two biologists, and one agronomist conducted fieldwork during 18 months, from May 1999 to November 2000. The study formed part of a long-term research in progress to measure the effect of markets on the quality of life of indigenous peoples (Godoy et al. 2005).

Setting: Recall that we want to examine the relation between plant uses and ethnobotanical knowledge by comparing villages with different levels of integration to the market economy. Therefore, to increase variation in dependence on the forest, we selected two villages at different distance to the local market town, San Borja (population 19,000). The first village, Yaranda (15'16.369 S, 66 '50.838 W), lies about 50 kilometers in a straight line from the town of San Borja, or three days canoeing upriver. Because of the high transportation cost, people from the village of Yaranda acquire most of their market goods through traders who come to the village. The second study site, San Antonio (14'48.698 S, 66'39.761 W), is 10 kilometers away, also in a straight line, from the town of San Borja, or about three hours walking at a normal pace. Because people can visit the town of San Borja and be back to the village on the same day, San Antonio represents a village less dependant on the forest.

Sampling: We interviewed all people over 15 years of age in the two villages. We chose 15 years as the cutoff age because most acquisition of traditional ecological knowledge occurs before the age of about 15 (Hunn 2002, Ohmagari \& Berkes 1997, Ruddle \& Chesterfield 1977, Zarger 2002) and because at this age Tsimane' adolescents start forming their own households. The total sample for the study included 132 adults, from which 59 $(45 \%)$ lived in the remote village of Yaranda and 73 (55\%) lived in the accessible village of San Antonio. The sample was almost evenly split between women (48\%) and men $(52 \%)$. The average age of subjects was 32.3 years (standard deviation=15.67).

Village ethnobotanical knowledge: To compile Tsimane' ethnobotanical knowledge we used free listings. Free list- ing consisted in asking 24 participants in the remote village and 24 participants in the accessible village to list useful plants. We asked participants to provide the name of all the useful plants they knew and all the uses of each plant in their list. We grouped the plants named in free listing into six categories: medicine, firewood, construction, tool, food, and other uses. Under the category tools and utensils we include mortars and platforms for grinding, food containers, mats, bags for keeping and carrying food, storage boxes, brooms, fabrics, bows, arrows, and weaving material. To be able to compare ethnobotanical knowledge and uses of plants, under the category 'other uses' we grouped uses that usually take place out of the household (e.g., canoe building) because those uses are not properly captured by the method we used to measure uses of plants (see below). Under the category 'other uses' we also included uses reported with less frequency (e.g., necklaces, dyes).

Individual ethnobotanical knowledge: To calculate individual ethnobotanical knowledge we conducted three multiple-choice tests, each time with a different set of plants randomly chosen from the results of free listing. The tests consisted in asking participants whether the plants could be used for construction, firewood, food, medicine, or for other uses. For each plant, participants could choose none, one, or more potential uses (Reyes-García et al. 2004).

Uses of plants: To capture uses of plants, we conducted weekly interviews over a year, from November 1999 until October 2000. Every week, at the end of a day chosen at random, we visited each household in both villages and asked each adult about the plants brought to the household during the previous 24 hours. We collected an average of 10.8 interviews per adult (standard deviations $=7.36$; $\min =1$; $\max =32$ ). When we visited the household, we recorded [a] the Tsimane' name of the plant species brought by each adult and [b] the intended use of the plant.

Specimens identification: We collected voucher specimens for all plants reported as useful. We deposited voucher specimens at the Herbario Nacional de Bolivia, Universidad Mayor the San Andrés, La Paz. A key informant identified plant specimens in the local vernacular and taxonomists from the herbarium provided the scientific nomenclature. We have described much of the Tsimane' ethnobotanical knowledge in a book in Tsimane' with partial Spanish translation (Nate et al. 2000), two dissertations (Huanca 1999, Reyes-García 2001), and an article (Reyes-García 2006).

Data analysis: To calculate scores of individual ethnobotanical knowledge, we equated knowledge with agreement between subjects and used a cultural consensus model to assess how much agreement a person displayed with the rest of the group (Romney et al. 1986, Reyes-García et al. 2004). For each individual we calcu- 
lated the average score based on the number of tests answered.

To analyze data on uses of plants, we calculated consumption of plants. Consumption of plants refers to the total number of plants that individuals brought to the households, independent of their intended use. We then calculated [1] village consumption of plants or the number of plants brought to the households of the two villages over a year, and [2] individual consumption of plants or the number of plants each adult brought to the household (plants/day).

\section{Results}

Village ethnobotanical knowledge: Participants mentioned a total of 233 different plants in free listing, which had a total of 355 different unique uses. People in the more remote village of Yaranda mentioned more plant species and more uses of plants than people in the more accessible village of San Antonio. The 24 participants in Yaranda mentioned an average of 51.1 uses of plants per respondent, whereas the 24 respondents in San Antonio mentioned an average of 26.6 uses of plants per respondent. In Yaranda, participants reported 191 plant species, which had a total of 298 uses, whereas in San Antonio participants mentioned 133 plant species, which had a total of 218 uses.

The most frequently mentioned uses of plants were medicine $(n=109 ; 31 \%)$, firewood $(n=73 ; 21 \%)$, and house construction ( $n=59 ; 17 \%)$ (Table 1). Participants also mentioned 53 different uses of plants to craft tools and utensils $(15 \%)$. We recorded 21 uses of plants as food $(6 \%)$, and 40 with other uses (11\%). Participants from the more remote village of Yaranda mentioned more uses of plants in all the categories of analysis except for food. Participants from San Antonio reported 18 food plants whereas participants from Yaranda only reported three food plants. In sum, participants from the most isolated village mentioned more plants and for more ends than participants from the closest village.

Individual ethnobotanical knowledge: With a range from 0 to 1 , individuals in the sample had an average score of ethnobotanical knowledge of $0.86(n=132$; standard deviation=0.09, $\min =0.43$, $\max =0.95$ ) (Table 2). We found statistically significant differences in the score of individual ethnobotanical knowledge between people in the two villages. People from the more remote village of Yaranda had higher ethnobotanical knowledge scores (mean $=0.91$; standard deviation $=0.09 ; n=74$ ) than people in the village of San Antonio (mean=0.81; standard deviation=0.03; $n=66$ ) (t-test of comparison of mean, $p<0.001$ ). The coefficient of variation (cv=standard deviation/mean) in scores of ethnobotanical knowledge was higher in San Antonio ( $c v=0.11$ ) than in Yaranda $(c v=0.03)$, suggesting more variability in respondent's ethnobotanical knowledge in San Antonio than in Yaranda.

Village consumption of plants: Over a year of weekly interviews, we observed 257 different uses of 171 different plants in the pooled sample. Most of the 171 plant

Table 1. Village knowledge of plant uses: Unique uses of plant species reported in free listing on two Tsimane' villages.

\begin{tabular}{|c|c|c|c|c|c|c|}
\hline \multirow[b]{2}{*}{ Use of plants } & \multicolumn{2}{|c|}{$\begin{array}{c}\text { Yaranda } \\
(n=24)\end{array}$} & \multicolumn{2}{|c|}{$\begin{array}{l}\text { San Antonio } \\
\quad(n=24)\end{array}$} & \multicolumn{2}{|c|}{$\begin{array}{c}\text { Total } \\
(n=48)\end{array}$} \\
\hline & Frequency & Percentage & Frequency & Percentage & Frequency & Percentage \\
\hline Medicine & 81 & 27.2 & 60 & 27.5 & 109 & 30.7 \\
\hline Firewood & 58 & 19.5 & 32 & 14.7 & 73 & 20.6 \\
\hline Construction & 46 & 15.4 & 32 & 14.7 & 59 & 16.6 \\
\hline Tools and utensils & 37 & 12.4 & 32 & 14.7 & 53 & 14.9 \\
\hline Food & 3 & 1.0 & 18 & 8.3 & 21 & 5.9 \\
\hline Other uses & 73 & 24.5 & 44 & 20.2 & 40 & 11.3 \\
\hline Total & 298 & 100 & 218 & 100 & 355 & 100 \\
\hline
\end{tabular}

Table 2. Individual knowledge and consumption of plants in two Tsimane' villages.

\begin{tabular}{|l|c|c|c|c|c|c|}
\hline \multirow{2}{*}{ Village } & \multicolumn{2}{|c|}{ Knowledge of plant uses (from 0 to 1) } & \multicolumn{3}{c|}{$\begin{array}{c}\text { Consumption of plants } \\
\text { Plants/day (from 0 to 3.2) }\end{array}$} \\
\cline { 2 - 7 } & Mean & Standard deviation & Observed & Mean & Standard deviation & Observed \\
\hline San Antonio & 0.81 & 0.09 & 74 & 0.77 & 0.35 & 69 \\
\hline Yaranda & 0.91 & 0.03 & 66 & 1.48 & 0.51 & 58 \\
\hline Total & $\mathbf{0 . 8 6}$ & $\mathbf{0 . 0 8}$ & $\mathbf{1 4 0}$ & $\mathbf{1 . 0 9}$ & $\mathbf{0 . 5 6}$ & $\mathbf{1 2 7}$ \\
\hline
\end{tabular}




\section{Reyes-Garcia et al. - Knowledge and Consumption of Wild Plants: A comparative study in two Tsimane' villages in the Bolivian Amazon}

species brought to the household were used for firewood ( $n=107 ; 42 \%)$. After firewood, Tsimane' used plants for tools and utensils $(n=34 ; 13 \%)$, medicine $(n=32 ; 13 \%)$, food $(n=29 ; 11 \%)$, and construction $(n=19,7 \%)$. We observed more uses of plant species in the remote village of Yaranda $(n=186)$ than in the accessible village of San Antonio $(n=117)$.

Each Tsimane' adult brings to the household an average of 394 plants every year (Table 3), most of them for firewood ( $n=254 ; 64 \%)$. Tsimane' also bring to their households an average of 40 plants a year to craft tools and utensils $(10 \%)$ and 34 to eat $(9 \%)$. Among the plants that Tsimane' consume annually, those used for medicine and construction represent less than $5 \%$ of total annual consumption.

People in the more remote village of Yaranda consumed more plants than people in the more accessible village of San Antonio. Tsimane' living in San Antonio brought to their households an average of 282 plants/year, whereas Tsimane' living in Yaranda brought almost twice as much, or 553 plants/year. We found that adults from the village of Yaranda brought more plants than adults from the village of San Antonio in all the categories of uses of plants (Table 3$)$. Eighty per cent $(n=223)$ of the plants entering households in San Antonio were used for firewood. Tsimane' from the village of San Antonio rarely brought plants to craft tools (21 plants/year, $8 \%$ ), eat (18 plants/ year, $6 \%$ ), cure (6 plants/year, $2 \%$ ), or build houses (5 plants/year, $2 \%$ ). In the village of Yaranda, each adult brought 295 plants/year to use as firewood (53\%), 66 $(12 \%)$ to craft tools, $57(10 \%)$ to eat, 32 to cure $(6 \%)$, and 20 to build houses (4\%). In the village of Yaranda, each adult also brought an average of 83 plants/year (15\%) with other uses (e.g necklaces, toys), whereas in the village of San Antonio, people brought only nine plants/year $(3 \%)$ for other uses.

Individual consumption of plants: On average, each adult in the sample brought home 1.1 plants every day (standard deviation=0.56; $n=127$ ). People from the village of Yaranda brought to their households more plants/day
( mean=1.48; standard deviation $=0.51 ; n=58$ ) than people from the village of San Antonio (mean=0.77; standard deviation $=0.35$; $n=69$ ) (t-test of comparison of means $p<0.01)$. We found a lower coefficient of variation in uses of plants in the village of Yaranda $(\mathrm{cv}=0.34)$ than in the village of San Antonio (cv=0.45).

Correlation between individual ethnobotanical knowledge and consumption of plants: We found a high, positive, and statistically significant correlation between individual ethnobotanical knowledge and individual consumption of plants (correlation coefficient $=0.49, \quad p<0.0001$, $n=127$ ). But this relation did not apply equally to the entire sample. In the more remote village of Yaranda we found a positive correlation between individual ethnobotanical knowledge and individual consumption of plants (correlation coefficient $=0.43, p=0.002, n=58$ ). We did not find a statistically significant correlation between individual ethnobotanical knowledge and individual consumption of plants in the village of San Antonio (correlation coefficient=0.05, $p=0.97, n=69$ ).

\section{Discussion and Conclusion}

Two noteworthy findings stand out from this work. First, our data suggests that people in the more isolated village know and consume more plants than people in the more accessible village. The finding is consistent whether analyzing the data at the village or at the individual level. Second, we found that individual ethnobotanical knowledge and individual consumption of plants correlate positively in the isolated village of Yaranda but not in the accessible village of San Antonio.

Why would individual ethnobotanical knowledge correlate positively with consumption of plants only in the isolated and not in the accessible village? In the more isolated village of Yaranda we found the expected positive correlation between individual ethnobotanical knowledge and uses of plants. In Yaranda, people who know more about uses of plants also use more plants. Contrary, in San Antonio, ethnobotanical knowledge and consumption of plants do not correlate. A possible explanation for

Table 3. Village consumption of plants (in plants/person/year).

\begin{tabular}{|l|c|c|c|c|c|c|}
\hline & \multicolumn{2}{|c|}{ Yaranda } & \multicolumn{2}{c|}{ San Antonio } & \multicolumn{2}{c|}{ Total } \\
\hline Use & Frequency & Percentage & Frequency & Percentage & Frequency & Percentage \\
\hline Medicine & 32.05 & 5.80 & 6.35 & 2.25 & 16.79 & 4.26 \\
\hline Firewood & 294.97 & 53.38 & 222.81 & 78.90 & 253.73 & 64.43 \\
\hline Construction & 19.59 & 3.54 & 4.77 & 1.69 & 10.79 & 2.74 \\
\hline Tools and utensils & 66.47 & 12.03 & 21.45 & 7.59 & 39.81 & 10.11 \\
\hline Food & 56.98 & 10.31 & 18.27 & 6.47 & 34.05 & 8.65 \\
\hline Other uses & 82.50 & 14.93 & 8.74 & 3.09 & 38.61 & 9.80 \\
\hline Total & $\mathbf{5 5 2 . 5 4}$ & $\mathbf{1 0 0 . 0 0}$ & $\mathbf{2 8 2 . 3 9}$ & $\mathbf{1 0 0 . 0 0}$ & $\mathbf{3 9 3 . 7 8}$ & $\mathbf{1 0 0 . 0 0}$ \\
\hline
\end{tabular}


the lack of correlation in the accessible village relates to the low level of consumption of plants in the village (about half of the average in the isolated village). Independent of the stock of ethnobotanical knowledge held by respondents in San Antonio, they all used few plants, presumably because they had better access to plant substitutes than people in the more isolated village of Yaranda. For example, although some people in San Antonio still remember plants that can be used as dyes, the introduction of synthetic colored yarn has displaced the daily use of natural dyes; over a year of interviews, we did not observe the use of any natural dye in San Antonio, although villagers in Yaranda still use natural dyes.

Researchers who have analyzed the relation between ethnobotanical knowledge and uses of plants have argued that the discrepancies between answers to surveys and actual uses stems from changes generated by the replacement of plants by commercial substitutes (Byg and Balslev 2001) or by changes in the way of life (Ladio and Lozada 2004). Our findings from the accessible village of San Antonio confirm those interpretations. However, our study also suggests that in situations where individual uses of plants are not subject to drastic changes, such as in the more autarkic village of Yaranda, individual ethnobotanical knowledge actually correlates with uses of plants.

In sum, results from our research suggest that ethnobotanical knowledge and uses of plants might correlate in autarkic settings, but as indigenous people become more integrated into the market economy and adopt plant substitutes, they stop using plants. Situations of rapid socio-economic changes might create a gap between people's ethnobotanical knowledge and their use of wild plants, thereby attenuating the correlation between knowledge and use. Uses of plants can change over a short time, without initially affecting individual ethnobotanical knowledge. Nevertheless, changes in uses of plants can generate long-run changes in ethnobotanical knowledge. Researchers could use the gap between ethnobotanical knowledge and actual uses of plants to study erosion of ethnobotanical knowledge.

\section{Acknowledgements}

Funds for this research came from the National Science Foundation (SBR-9731240 and SBR-9904318), the John D. and Catherine T. MacArthur Foundation, the Conservation, Food and Health Foundation, the Central de Pueblos Indígenas del Oriente Boliviano, and the Wenner-Gren Foundation (Gr-7250). We would like to thank Wendy Tonwsend for encouraging the research. We thank the Gran Consejo Tsimane', Lilian Apaza, Elizabeth Byron, Damian Ista, Alonzo Nate, Javier Pache, and Eddy Pérez for their support with fieldwork and logistics. We thank R Godoy, W. McClatchey and an anonymous reviewer for comments on previous drafts of the article.

\section{Literature Cited}

Atran S, D. Medin, N. Ross, E. Lynch, V. Vapnarsky, E. Ucan, J. Coley, C. Timura \& M. Baran. 2002. Folkecology, Cultural epidemiology, and the Spirit of the Commons. A Garden Experiment in the Maya Lowlands, 1991-2001. Current Anthropology 43:421-51.

Begossi, A. 1996. Use of ecological methods in ethnobotany: Diversity indices. Economic Botany 50:280-289.

Begossi A., N. Hanazaki \& J. Tamashiro. 2002. Medicinal plants in the Atlantic Forest (Brazil): knowledge, use, and conservation. Human Ecology 30:281-299.

Benz, B.F., J. Cevallos, F. Santana, J. Rosales \& S. Graf. 2000. Losing knowledge about plant use in the sierra de Manantlan Biosphere Reserve, Mexico. Economic Botany 54:183-191.

Byg, A. \& H. Balslev. 2001. Traditional knowledge of Dypsis fibrosa (Aracaceae) in Eastern Madagascar. Economic Botany 55:263-275.

Byron, E. 2003. Market Integration and Health: The Impact of Markets on the Nutritional Status, Morbidity, and Diet of the Tsimane' Amerindians of Lowland Bolivia. University of Florida.

Casagrande, D.G. 2002. Ecology, Cognition, and Cultural Transmission of Tzeltal Maya Medicinal Plant Knowledge. Ph.D. dissertation. University of Georgia.

Chicchon, A. 1992. Chimane Resource Use and Market Involvement in the Beni Biosphere Reserve, Bolivia. Ph.D. dissertation. University of Florida.

Ellis, R. 1996. A Taste for Movement: An Exploration of the Social Ethics of the Tsimane' of Lowland Bolivia. Ph.D. dissertation. St. Andrews University, Scotland.

Figueiredo, G.M., H. Leitao-Filho \& A. Begossi. 1997. Ethnobotany of Atlantic Forest Coastal Communities: Diversity of Plant Uses at Sepetiba Bay (SE Brazil). Human Ecology 25:353-360.

Godoy, R., N. Brokaw, D. Wilkie, D. Colón, A. Palermo, S. Lye \& S. Wei. 1998. Of trade and cognition: Markets and the loss of folk knowledge among the Tawahka indians of the Honduran Rain Forest. Journal of Anthropological Research 54:219-233.

Godoy, R., H. Overman, J. Demmer, L. Apaza, E. Byron, T. Huanca, W. Leonard, E. Perez, V. Reyes-Garcia, V. Vadez, D. Wilkie, A. Cubas, K. McSweeny \& N. Brokaw. 2002. Local financial benefits of rain forests: Comparative evidence 


\section{Reyes-Garcia et al. - Knowledge and Consumption of Wild Plants: A comparative study in two Tsimane' villages in the Bolivian Amazon}

from Amerindian societies in Bolivia and Honduras. Ecological Economics 40:397-409.

Godoy, R., V. Reyes-García, E. Byron, W. Leonard \& V. Vadez. 2005. The effect of market economies on the wellbeing of indigenous peoples and on their use of renewable natural resources. Annual Review of Anthropology $34: 121-138$

Hewlett, B.S. \& L.L. Cavalli-Sforza. 1986. Cultural transmission among Aka Pygmies. American Anthropologist 88:922-934.

Huanca T. 1999. Tsimane' Indigenous Knowledge. Swidden Fallow Management and Conservation. Ph.D. dissertation. University of Florida.

Hunn, E.S. 2002. Evidence for the Precocious Acquisition of Plant Knowledge by Zapotec Children. Pp. 604-613 in Ethnobiology and Biocultural Diversity. Edited by J.R. Stepp, F.S. Wyndham \& R. Zarger. International Society of Ethnobiology, Athens, Georgia.

Killeen, T., E. Garcia \& S. Beck. 1993. Guia de Arboles de Bolivia. Herbario Nacional de Bolivia y Missouri Botanical Gardens, La Paz, Bolivia.

Ladio, A. \& M. Lozada. 2004. Patterns of use and knowledge of wild edible plants in distinct ecological environments: a case study of a Mapuche community from northwestern Patagonia. Biodiversity and Conservation 13:1153-1173.

Nate, A., D. Ista \& V. Reyes-Garcia. 2000. Plantas Utiles y su Aprovechamiento en la Comunidad Tsimane'de Yaranda. CIDOB-DFID, Santa Cruz.

Ohmagari, K. \& F. Berkes. 1997. Transmission of Indigenous Knowledge and Bush Skills Among the Western James Bay Cree Women of Subartic Canada. Human Ecology 25:197-222.

Phillips, O. 1996. Some quantitative methods for analyzing ethnobotanical knowledge. Pp. 171-197 in Selected guidelines for ethnobotanical research: a field manual. Edited by M. Alexiades. New York Botanical Garden Press, Bronx, New York.

Reyes-García, V. 2001. Indigenous People, Ethnobotanical Knowledge, and Market Economy. A Case Study of the Tsimane'Amerindians, Bolivia. Ph.D. dissertation. University of Florida.

Reyes-García, V., E. Byron, R. Godoy, V. Vadez, L. Apaza, E. Pérez, W. Leonard \& D. Wilkie. 2004. Measuring culture as shared knowledge: Do data collection formats matters? Cultural knowledge of plant uses among the Tsimane' Amerindians of Bolivia. Field Methods 16:135-156.
Reyes-García, V., R. Godoy, V. Vadez, L. Apaza, E. Byron \& E. Pérez. 2003. Ethnobotanical Knowledge Shared Widely Among Tsimane 'Amerindians, Bolivia. Science 299:1707.

Reyes-García, V., T. Huanca, V. Vadez, W. Leonard, and D. Wilkie. 2006. Cultural, practical, and economic value of wild plants: A quantitative study in the Bolivian Amazon. Economic Botany 60:In Press.

Reyes-García, V., V. Vadez, E. Byron, L. Apaza, W. Leonard, E. Pérez \& D. Wilkie. 2005. Market economy and the loss of ethnobotanical knowledge: Estimates from Tsimane' Amerindians, Bolivia. Current Anthropology 46:651656.

Romney, A.K., S. Weller \& W. Batchelder. 1986. Culture as consensus: A theory of culture and informant accuracy. American Anthropologist 88:313-338.

Rossato, S.V.C., H. Leitao-Filho \& A. Begossi. 1999. Ethnobotany of Caicaras of the Atlantic Forest Coast (Brazil). Economic Botany 53:387-395.

Ruddle, K. \& R. Chesterfield. 1977. Education for Traditional Food Procurement in the Orinoco Delta. University of California Press, Berkeley.

Vadez, V., V. Reyes-García, L. Apaza, E. Byron, T. Huanca, W. Leonard, E. Pérez \& D. Wilkie. 2004. Does integration to the market threaten agricultural diversity? Panel and cross-sectional evidence from a horticultural-foraging society in the Bolivian Amazon. Human Ecology 32:635646.

Zarger, R. 2002. Acquisition and Transmission of Subsistence Knowledge by Q'eqchi' Maya in Belize. Pp. 592-603 in Ethnobiology and Biocultural Diversity. Edited by J.R. Stepp, F.S. Wyndham \& R. Zarger. International Society of Ethnobiology, Athens, Georgia.

Zarger, R. \& J.R. Stepp. 2004. Persistence of botanical knowledge among Tzeltal Maya Children. Current Anthropology 45:413-418.

Zent, S. 2001. Acculturation and Ethnobotanical Knowledge Loss among the Piaroa of Venezuela: Demonstration of a Quantitative Method for the Empirical Study of Traditional Ecological Knowledge Change. Pp. 190-211 in On Biocultural Diversity: Linking Language, Knowledge, and the Environment. Edited by L. Maffi. Smithsonian Institution Press, Washington, D.C. 
